Manson, E. E. D., Pollock, M. R. \& Tridgell, E. J. (1954). J. gen. Microbiol. 11, 493-505.

\title{
A Comparison of the Properties of Penicillinase produced by Bacillus subtilis and Bacillus cereus with and without Addition of Penicillin
}

\author{
By EILEEN E. D. MANSON, M. R. POLLOCK \\ AND E. J. TRIDGELL \\ National Institute for Medical Research, Mill Hill, London, N.W. 7
}

\begin{abstract}
SUMMARY: The properties (Michaelis constants, rates of inactivation at $100^{\circ}$, temperature coefficients and $\mathrm{pH} /$ activity relationships) of the extracellular penicillinase formed by a strain of Bacillus subtilis when growing in casein hydrolysate ( = 'basal' enzyme) have been compared with those of the enzyme formed by the organism when growing in the same medium after addition of 1 unit benzylpenicillin/ml. ( = 'induced' enzyme); no differences between the two preparations were detected. Similarly, no immunological or other differences were found between the basal and induced penicillinases of B. cereus, strain 569. However, the B. subtilis penicillinase was significantly different from the $B$. cereus penicillinase in the value of its Michaelis constant and the shape of its $\mathrm{pH} /$ activity curve; it was also quite distinct immunologically.
\end{abstract}

In most cases of microbial enzyme adaptation ('induced enzyme synthesis') the effect of the inducer is to cause a specific increase in activity of an enzyme which is, nevertheless, present to some extent in untreated cells. This spontaneously produced enzyme has been referred to as 'constitutive' or 'basal'; and, according to the enzyme and organisms concerned, may form a considerable or very minute fraction of that formed under influence of the inducer. In some instances no basal or constitutive enzyme activity has been detectable. With the $\beta$-galactosidase of Escherichia coli ML studied by Monod and his colleagues, Cohen-Bazire \& Jolit (1953) showed that the trace of basal activity found in cultures grown in maltose could be explained by the known presence of a small proportion of mutant cells which were capable of forming large quantities of the enzyme constitutively. How far the property of producing an enzyme spontaneously (i.e. without added inducer) is distributed equally amongst a cell population, may in most cases be largely unknown, but in general, the process of enzyme adaptation must be regarded as an increase in the rate of production of an enzyme which is formed to some extent in the absence of the inducer, and not a formation de novo. The question is thus posed: Is constitutive (basal) enzyme composed of the same molecular species as induced enzyme, and if so, to what extent do the processes leading to their formation follow the same metabolic pathway?

In the work reported here an attempt has been made to obtain an answer to the first part of the question by a comparative study of the biochemical properties of penicillinases from a strain (749) of Bacillus subtilis and from a strain (569) of B. cereus formed (a) spontaneously, and $(b)$ under the influence of benzylpenicillin. This problem has not been studied systematically before. 
Reiner \& Spiegelman (1947), however, claimed that the 'affinity constant' of galactozymase $\left(\mathrm{O}_{2}\right.$ uptake by intact cells of Saccharomyces cerevisiae in the presence of galactose) was over 8 times higher in unadapted cells than in those which had been previously adapted to galactose oxidation. It seems possible, however, that the $\mathrm{O}_{2}$-uptake by unadapted cells in presence of galactose in these experiments, was not in fact due to galactose metabolism, but to the oxidation of traces of glucose and ethanol present in the sample of galactose used. It was shown by Lindegren \& Palleroni (1952) that glucose and ethanol were present in samples of galactose prepared by the method used by Reiner \& Spiegelman. Bernheim (1950), studying the adaptive sarcosine oxidase system in Pseudomonas aeruginosa, reported that the basal activity was unaffected by sodium dodecyl sulphate at concentrations which caused $32 \%$ inhibition of enzyme in cells adapted by treatment with creatinine. He concluded that the adaptively-formed enzyme was on or near the cell-surface while the basal enzyme was inside the cell and so protected. Monod \& Cohn (1952), however, found no differences, either immunological or biochemical, with respect to the relative activity on, or affinity for, different substrates, as between the constitutive (basal) and induced $\beta$-galactosidases of various strains of Escherichia coli. Indeed, in this case, there appeared to be no detectable immunological or biochemical differences between $\beta$-galactosidases produced by organisms in three separate bacterial genera $(E$. coli, Shigella sonnei and Aerobacter aerogenes), although the $\beta$-galactosidases formed by Lactobacillus bulgaricus and by Saccharomyces fragilis were distinct, both from the first group and from each other (see also Cohn \& Torriani, 1953).

The penicillinases from the two species of Bacillus chosen for this work were especially suitable because $(a)$ the enzymes are released into the culture fluid and can be conveniently studied in a cell-free state without further treatment; (b) although the inducer (penicillin) markedly and specifically stimulates enzyme production-causing a 10 - to 20 -fold increase with $B$. subtilis, strain 749 , and a 200 - to 500 -fold increase with $B$. cereus, strain 569-there is an accurately measurable amount of basal activity (especially in organism 749) present in the control untreated culture; $(c)$ it seems reasonable to assume that the basal activity is really produced by the cells spontaneously, since there can hardly be traces of penicillin in the casein hydrolysate or peptone medium used.

Ideally, a comparison of two similar enzymes should be made with fully purified preparations. This would not only allow a more accurate comparison, but extend the range of properties that could be compared. However, although the induced enzyme of Bacillus cereus, strain 569, has been purified (Pollock \& Torriani, 1953), the immediate chances of obtaining enough of the basal enzyme of either species (where the amount produced is not more than 1/100 of that formed by organism 569 after induction) in a fully purified state are obviously remote. The next best alternative thus appeared to be the use of simple cell-free supernatant fluids from cultures grown in the same medium and, as far as possible, under the same conditions for both basal and induced enzyme preparations. 


\section{METHODS}

\section{Organisms}

(a) Bacillus subtilis, strain 749, kindly sent by Mr Leeson of the Distillers Co., Liverpool. This organism (under the label ' $B$ ') was used in previous studies (Manson \& Pollock, 1953) on the thermostability of different penicillinases, but was erroneously classified as a strain of $B$. cereus (Leeson, 1950). Its small cell size and the fact that we found it would grow on $\mathrm{NH}_{3}$ as sole source of $\mathbf{N}$ and without added growth factors indicate that it should be regarded as a $B$. subtilis.

(b) B. cereus, strain NRRL 569, used previously for studies on penicillinase adaptation.

\section{Media and materials}

Penicillin : crystalline sodium benzylpenicillin from Glaxo Laboratories Ltd. Gelatin: Difco 'standardized'.

Casein hydrolysate medium (CH): $0 \cdot 8 \%(w / v)$ acid hydrolysed 'vitaminfree' casein (Allen and Hanburys) supplemented by $M / 600 \mathrm{MgSO}_{4}, \mathrm{M} / \mathbf{5 0}$ sodium-potassium phosphate buffer $(\mathrm{pH} 7 \cdot \mathbf{0}), \mathbf{M} / \mathbf{1 2 , 5 0 0}$ tryptophan and $\mathrm{m} / 5000$ cystine.

' $S$ ' broth: $1 \%(w / v)$ peptone (Evans) + 0.3\% (w/v) Lab-Lemco (pH 7.0), prepared as described by Pollock \& Perret (1953).

Tryptic digest broth (Hartley, 1922); CCY medium (Gladstone \& Fildes, 1940).

\section{Penicillinase assay}

Except in the $\mathrm{pH} /$ activity experiments, the enzyme was assayed at $30^{\circ}$ in bicarbonate $/ \mathrm{CO}_{2}$ buffer at $\mathrm{pH} \mathbf{7 \cdot 0}$ by the manometric method of Henry \& Housewright (1947). No corrections were made for the slight degree of $\mathrm{CO}_{2}$ retention which occurs, since the flask constants did not vary enough for such retention to affect comparative results. For $\mathrm{pH} /$ activity experiments the iodimetric method of Penau, Phillipe \& Benoist (1951), as modified and improved by Perret (private communication), was used, since a wide range of $\mathrm{pH}$ values is not attainable by the manometric method. The iodimetric method estimates directly the penicilloic acid formed. When all the necessary controls are used in order to correct for spontaneous decomposition of penicillin, this method can be extremely accurate and is particularly useful for the detection of differences in the low enzymic activities found at $\mathrm{pH}$ values some way from the optimum. All activities are expressed as $\mu$ mole penicillin destroyed/hr. at $30^{\circ}$ (= penicillinase units as defined by Pollock \& Torriani, 1953).

\section{Penicillinase production}

Bacillus subtilis, strain 749. (a) Basal enzyme. In order to obtain enough enzyme in the cell-free culture fluid, one-fifth of the cells from a spore-inoculated nutrient agar slope, incubated for $16 \mathrm{hr}$. at $35^{\circ}$, were used to inoculate $50 \mathrm{ml}$. of $\mathrm{CH}$ medium which was then shaken aerobically at $35^{\circ}$ for $24 \mathrm{hr}$. The cells were immediately centrifuged off and the supernatant fluid, having 
an activity of from 5 to 10 penicillinase units $/ \mathrm{ml}$., was adjusted to $\mathrm{pH} \mathbf{7 \cdot 0}$ and stored at $2^{\circ}$. (b) Induced enzyme. Cells from a spore-inoculated liquid CCY medium shaken for $24 \mathrm{hr}$. at $35^{\circ}$, were washed and shaken in $50 \mathrm{ml}$. $\mathrm{CH}$ medium containing 1 unit penicillin $/ \mathrm{ml}$. at an initial opacity corresponding to $1.5 \mathrm{mg}$. dry-wt. bacteria $/ \mathrm{ml}$., at $35^{\circ}$ for $3.5 \mathrm{hr}$. The penicillinase activity in the supernatant fluid, after removal of cells, was $15-30$ units $/ \mathrm{ml}$. The preparation was treated and stored in the same way as the basal fraction. Both the total and exocellular penicillinase activities of these induced cultures were about 7 times those obtained in cultures similarly prepared but without addition of penicillin. It is thus reasonable to conclude that the maximum possible proportion of basal enzyme present in the 'induced' preparation was $15 \%$.

Bacillus cereus, strain 569. (a) Basal enzyme. $50 \mathrm{ml}$. of ' $\mathrm{S}$ ' broth were inoculated with 1 drop of a spore suspension containing $3 \times 10^{8}$ viable cells $/ \mathrm{ml}$., and incubated at $35^{\circ}$ on a shaker for $c .6 \mathrm{hr}$., by which time cell growth was equivalent to $1.0 \mathrm{mg}$. dry weight cells $/ \mathrm{ml}$. The cells were centrifuged off and the supernatant fluid kept at $2^{\circ}$ after addition of gelatin to $1 \%$ (final) to stabilize enzyme. The penicillinase activity of this fluid was usually about $1 \mathrm{unit} / \mathrm{ml}$. and it was therefore concentrated, when higher activities were necessary, by freeze-drying. (b) Induced enzyme was prepared in exactly the same way, except that penicillin ( $1 \mathrm{unit} / \mathrm{ml}$.) was added when the cell concentration was equivalent to $0 \cdot 1 \mathrm{mg}$. dry wt. bacteria $/ \mathrm{ml}$. Activities reached values up to 500 units penicillinase $/ \mathrm{ml}$.

\section{RESULTS}

\section{Inactivation by heat}

Loss of enzyme activity at boiling-water bath temperature was followed by the technique of Manson \& Pollock (1953). It had been found that gelatin or high molecular weight substances present in tryptic digest broth afforded considerable protection. Basal and induced enzyme preparations from Bacillus subtilis, strain $\mathbf{7 4 9}$ grown in nutrient broth, as well as preparations from cultures grown in $\mathrm{CH}$ medium, were examined (Table 1). No significant differences in the rates of inactivation of the basal and induced enzyme preparations were found, and the degree of protection afforded by the presence of nutrient broth was the same for both.

Previous work (Manson \& Pollock, 1953) revealed some apparently signifi-

Table 1. Rates of inactivation at $100^{\circ}$ of induced and basal penicillinase of Bacillus subtilis, strain $\mathbf{7 4 9}$

\begin{tabular}{clcccc} 
& & \multicolumn{4}{c}{$\begin{array}{c}\% \text { original activity remaining after } \\
\text { treatment at } 100^{\circ} \text { for }\end{array}$} \\
Growth medium & Enzyme & 2 min. & 5 min. & 16 min. & 60 min. \\
Casein & Induced & 31 & 19 & 11 & 7 \\
hydrolysate & Basal & 40 & 27 & 18 & - \\
Broth & Induced & 75 & 85 & 70 & 50 \\
& Basal & 85 & 83 & 72 & 42
\end{tabular}


cant differences in rate of thermal inactivation of penicillinase preparations from different organisms, and in the protective effect of added gelatin or broth. For instance, the penicillinase of Bacillus subtilis, strain 749 , is only $20 \%$ inactivated after $5 \mathrm{~min}$. at $100^{\circ}$ in the presence of $1 \%$ gelatin or tryptic digest broth, while the enzyme of $B$. cereus, strain 569 , is $55 \%$ destroyed under similar conditions. It is, however, possible that the smaller protective effect of gelatin for penicillinase from B. cereus, strain 569, may be due, in part at least, to the known presence of a gelatinase (not detected in $B$. subtilis, strain 749). For this reason, no heat inactivation studies were done with $B$. cereus, strain 569.

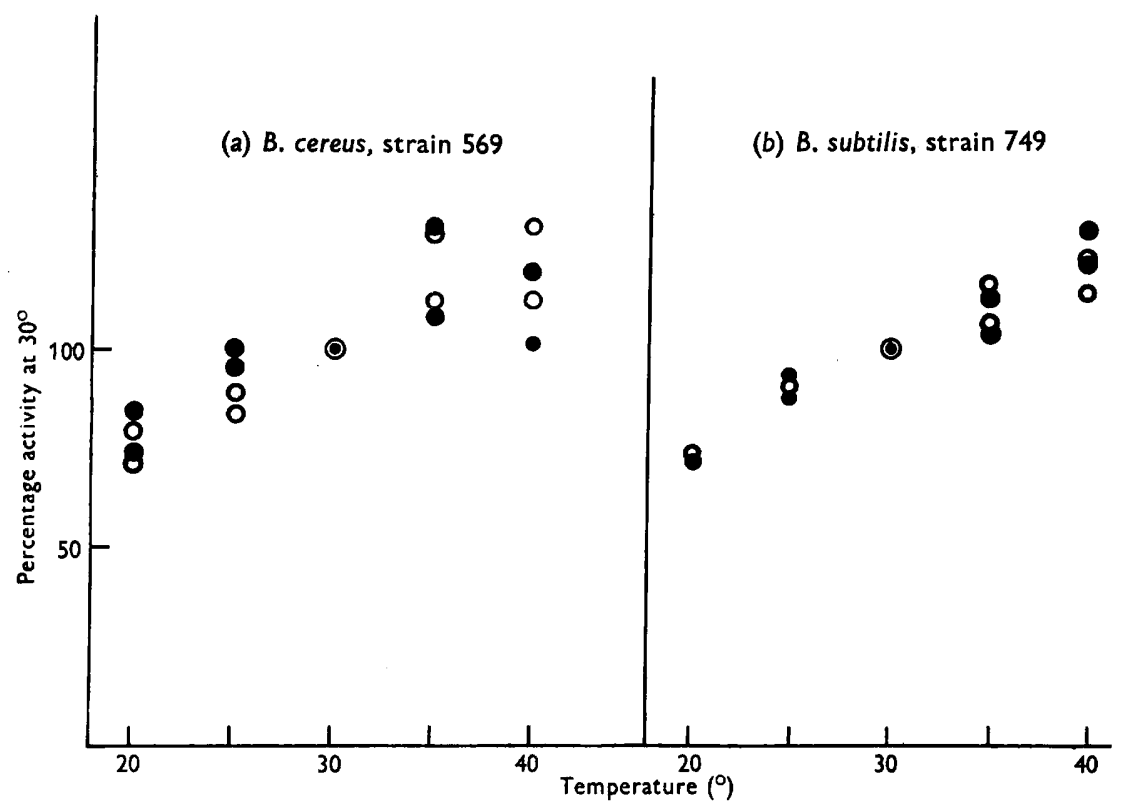

Fig. 1. Relationship between penicillinase activity and temperature for basal $(\bullet)$ and induced $(O)$ enzyme preparations from $(a) B$. cereus, strain 569 , and $(b) B$. subtilis, strain 749, expressed as percentage of respective activities at $30^{\circ}$. Each point is the mean of duplicate estimations made on each of two batches (plotted separately) of each enzyme, prepared on different occasions.

\section{Temperature coefficient}

Activities of the two preparations from both organisms at temperatures between $20^{\circ}$ and $40^{\circ}$ were compared after diluting the induced enzyme with fresh medium to give the same activity as the basal enzyme and adding gelatin to $1 \%$ to prevent possible inactivation at the higher temperatures. The activity curves (Fig. 1), representing results with two preparations of basal and induced enzyme from both organisms, show no significant differences either between basal and induced enzymes, or between the enzymes from the two different species. 


\section{$\mathrm{pH} /$ activity curves}

All preparations were diluted in $0.5 \%$ gelatin to give an activity of $c .3 \cdot 0$ units/ml. (as measured at $\mathrm{pH} 7 \cdot 0$ by the manometric method) and their activities at $30^{\circ}$ compared between $\mathrm{pH} 4.0$ and 8.0 using $\mathrm{M} / 5$ citrate buffer for the $\mathrm{pH}$ range $4 \cdot 0-6 \cdot 0$ and phosphate buffer for $\mathrm{pH} 6 \cdot 0-8 \cdot 0$, so that overlap with the two different buffers was obtained at $\mathrm{pH} 6 \cdot 0$. Fig. $2 a, b$ shows the curves obtained when activities are expressed as percentages of the maximum (at pH 6.0). Measurements at $\mathrm{pH} 4 \cdot 0$ with enzyme from Bacillus subtilis, strain 749 , were inevitably rather inaccurate because of $(a)$ the very low absolute activities, and $(b)$ spontaneous decomposition of penicillin to penicilloic acid was 4 times that due to enzymic hydrolysis. In all other cases duplicates agreed to within $5 \%$ of the mean. A repeat experiment, using different batches of all four enzyme preparations, gave curves which were indistinguishable from those of the first experiment. It was confirmed, by titrating an enzyme-inactivated sample of penicillin after incubation at different $\mathrm{pH}$ values, that decomposition of penicilloic acid (which reacts specifically with the iodine and is thus assayed directly in this method), even at $\mathrm{pH} 4.0$ was not sufficient to interfere with results. It can be seen that while the curves for penicillinases from the two species are significantly different on the acid side of neutrality, there is very little difference between basal and induced enzyme in either case.

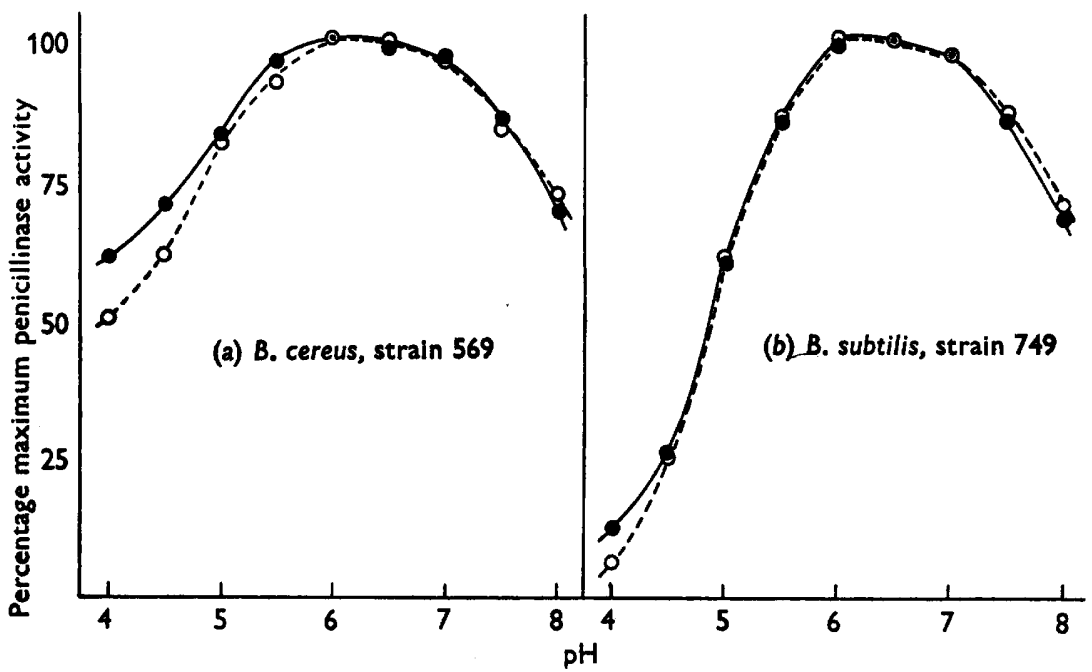

Fig. 2. Relationship between penicillinase activity and $\mathrm{pH}$ for basal (-O-O-) and induced (-O-O-) enzyme preparations from $(a) B$. cereus, strain 569 , and $(b) B$. subtilis, strain 749, expressed as percentage of their respective maximal activities (at pH 6.0). Each point is the mean of duplicate estimations of activity.

\section{Affinity constants .}

Preliminary tests soon indicated that the Michaelis constant of penicillinase was too low to permit even an approximate estimation by the direct manometric technique. Attempts to estimate low concentrations of penicillin by 
means of the cup assay were also unsuccessful since it was found necessary to inactivate the enzyme in order to obtain reproducible results, and this could not be done (e.g. by heat) without considerable loss of penicillin.

An alternative method based on the rate of penicillinase formation by Bacillus cereus, strain 569, in response to submaximal quantities of penicillin, was therefore evolved. It was found (Pollock, 1952) that there is a fairly good linear relationship between the rates of penicillinase formation by a log-phase culture of $B$. cereus, strain 569, growing in broth and the concentrations of penicillin added as inducer, within the range $0 \cdot 01-0 \cdot 10$ units penicillin $/ \mathrm{ml}$. The 'primary interaction' between penicillin and cells which initiates this enzymic induction is so rapid ( $50 \%$ complete in $60 \mathrm{sec}$.) that it is uninfluenced by the penicillin-destroying effect of small amounts of penicillinase added at the time and thus affords a means of estimating very low penicillin concentrations in the presence of penicillinase. There is thus no need to add any enzyme inactivator.

The enzyme sample was diluted in ' $S$ ' broth containing $1 \%$ gelatin to such a degree that, when diluted $1 / 10$, about half the penicillin at the particular concentration being tested would be destroyed in $45 \mathrm{~min}$. at $30^{\circ}$. At intervals of $15 \mathrm{~min} ., 1 \mathrm{ml}$. samples of the enzyme solution were added to four separate tubes containing $9 \mathrm{ml}$. of the appropriate concentration of penicillin in $1 \%$ gelatin ' $S$ ' broth. All tubes were removed from the bath at the time of addition of enzyme to the fourth tube and diluted, when necessary, so that the final penicillin concentrations fell between 0.04 and $0.20 \mathrm{unit} / \mathrm{ml}$. At the same time two known concentrations of penicillin in $1 \%$ gelatin ' $S$ ' broth were prepared containing 0.04 and $0.20 \mathrm{unit} / \mathrm{ml}$.

The test culture itself was prepared by inoculating $50 \mathrm{ml}$. ' $\mathrm{S}$ ' broth with 1 drop of a standard spore inoculum $\left(3 \times 10^{8}\right.$ viable cells $/ \mathrm{ml}$.) of Bacillus cereus, strain 569, and shaking at $35^{\circ}$ until the cell concentration was equivalent to. c. $0 \cdot 4 \mathrm{mg}$. dry wt./ml. This took $4-4.5 \mathrm{hr}$. Gelatin was added to a final concentration of $1 \%$ and $5 \mathrm{ml}$. lots were placed in six $50 \mathrm{ml}$. conical flasks shaking in a $35^{\circ}$ water-bath. At this point $5 \mathrm{ml}$. of unknown or standard samples, prepared as above, were added as rapidly as possible, each to one flask of test culture. Shaking of the flasks was continued and $2.5 \mathrm{ml}$. samples were transferred at 30 and $60 \mathrm{~min}$. into iced oxine for assay as in an ordinary adaptation experiment (Pollock, 1952). Penicillinase activities were measured manometrically and the rates of enzyme formation (difference between 60 and $30 \mathrm{~min}$. values) calculated. The penicillin concentrations are directly proportional to these and can thus be read off on the standard curve. The rates of penicillin destruction were measured as the mean rate over the period when not more than half the penicillin had disappeared.

In practice this very unorthodox method gave reasonably consistent and accurate assays of penicillin. Thus rates of penicillinase formation following induction at a penicillin concentration of $0 \cdot 10 \mathrm{unit} / \mathrm{ml}$. showed a variation of $\pm 7.5 \%$ about the mean in a series of five identical flasks. One major advantage, for calculation of the Michaelis constant, is that it is possible to measure rates of penicillin hydrolysis over a wide range of initial penicillin concentrations which are well below enzyme saturation. The constants have been 
calculated by direct substitution of the velocity found at the given initial penicillin concentration, in the Michaelis formula:

$$
V=\frac{V_{\max .} \times[S]}{[S]+K_{m}}
$$

where $V$ is the reaction velocity at substrate concentration $S, V_{\max }$ is the velocity when the enzyme is saturated by substrate, and $K_{m}$ the Michaelis constant. $\quad V_{\max }$. was measured, by the same technique, using an initial penicillin concentration of 500 units $/ \mathrm{ml} .\left(8.5 \times 10^{-4} \mathrm{M}\right)$ and an enzyme activity of 0.5 unit penicillinase/ml., giving results within $10 \%$ of those obtained by the manometric technique, with a penicillin concentration of $3300 \mathrm{units} / \mathrm{ml}$.

The constants, thus calculated, using initial penicillin concentrations of 0.2-200 units $/ \mathrm{ml}$., vary at most $59 \%$ above to $29 \%$ below the mean, including the least accurate value (obtained at 200 units $/ \mathrm{ml}$.), when the enzyme of Bacillus subtilis, strain 749 , is $60 \%$ saturated. Table 2 shows the results obtained. As with the $\mathrm{pH} /$ activity curves the similarity of the values for basal and induced enzyme preparations from the same strain is made more striking by the significant difference $(P=<0 \cdot 001)$ between the enzymes of the two species.

Table 2. Michaelis affinity constants of induced and basal penicillinases of Bacillus subtilis, strain 749, and Bacillus cereus, strain 569

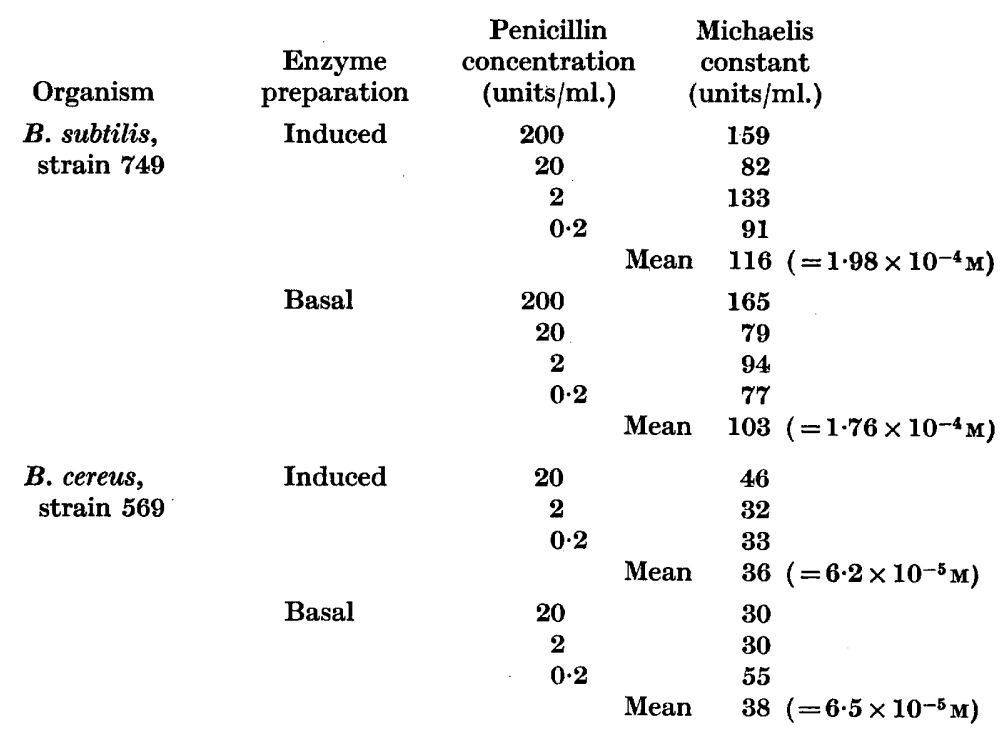

The Michaelis constants were calculated by direct substitution of measured velocities for each substrate concentration (for details, see text).

\section{Immunological properties}

After most of this work was complete, a specific neutralizing antiserum to induced penicillinase of Bacillus cereus, strain 569, was obtained by repeated injections of large amounts of purified enzyme into rabbits. Full details of the 
technique will be published later. This anti-penicillinase serum caused c. $95 \%$ inhibition of the penicillinase of $\boldsymbol{B}$. cereus, strain 569 , and gave constant ratios of antiserum added:penicillinase neutralized, when enzyme was in excess, at all concentrations of enzyme or antibody, irrespective of the medium. By contrast, a sample of the induced penicillinase of $B$. subtilis, strain 749 , was completely uninhibited by 5 times the dose of antiserum necessary to neutralize the equivalent amount of enzyme from $B$. cereus, strain 569 . The penicillinases from the two species are therefore immunologically distinct. However, the induced enzyme from $B$. cereus, strain 569, was inhibited to the same extent by a given amount of antiserum as was the basal enzyme from the same organism (see Fig. 3).

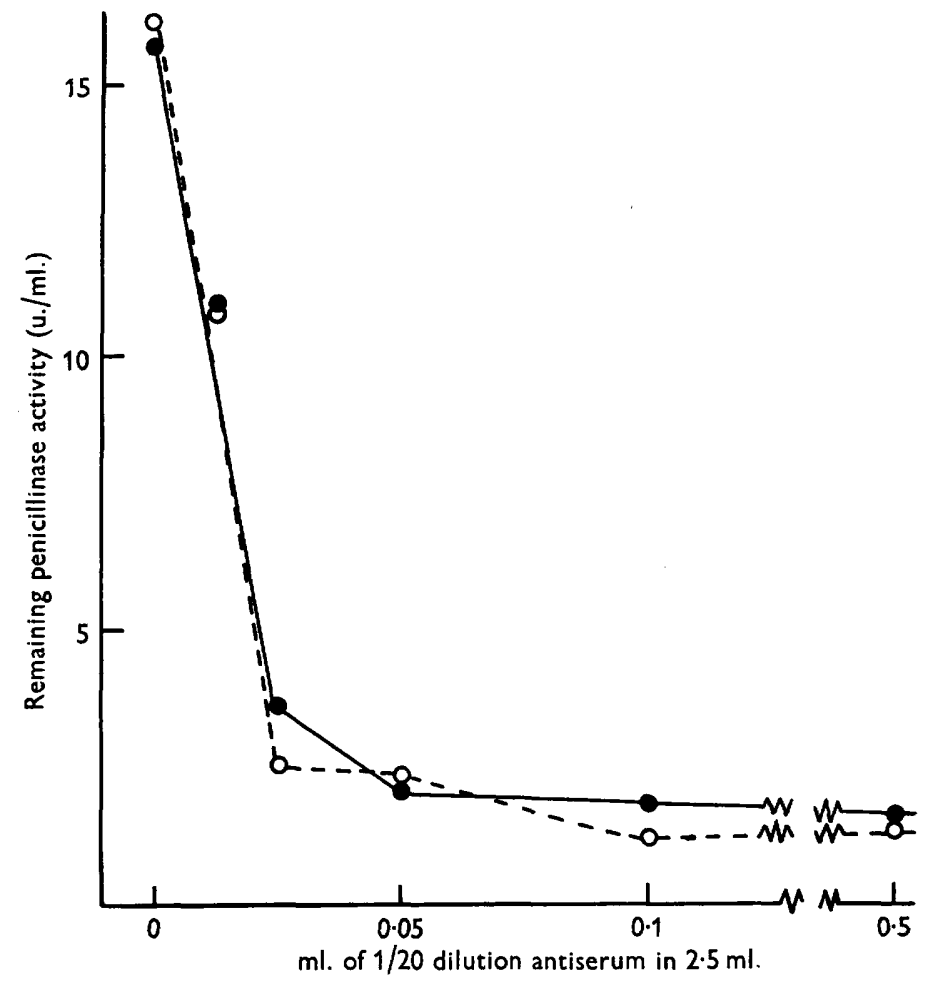

Fig. 3. Neutralizing effect of rabbit antiserum prepared against purified $B$. cereus, strain 569 , induced penicillinase, when mixed with samples of $B$. cereus, strain 569 , basal $\left(-\mathrm{O}_{-}\right)$and induced $(-\mathrm{O}-\mathrm{O}-)$ penicillinase.

Ratio of activities on $\mathrm{n}$-heptylpenicillin and benzylpenicillin

Henry \& Housewright (1947) reported that the ratio of the rate of hydrolysis of $n$-heptylpenicillin (Penicillin $\mathbf{K}$ ) to that of benzylpenicillin (Penicillin G) by Bacillus cereus, strain 569 , was from 0.59 to $0 \cdot 69$. This ratio was therefore measured for the basal and induced penicillinases of both $B$. subtilis, strain 749 , and $B$. cereus, strain 569, prepared as described above. The results, summarized in Table 3, indicate no difference in the ratio obtained with any of the four 
preparations. The $n$-heptylpenicillin was kindly supplied by $\operatorname{DrJ}$. H. Humphrey and contained only $10 \%$ of other penicillins (mainly penicillin dihydro F).

Table 3. Relative activities of induced and basal penicillinases of Bacillus subtilis, strain 749, and Bacillus cereus, strain 569, on penicillin $K$ and $G$

\begin{tabular}{|c|c|c|c|c|}
\hline \multirow[b]{3}{*}{ Organism } & \multicolumn{4}{|c|}{ Ratios of $\frac{\text { activity on pen. } K}{\text { activity on pen. } G}$} \\
\hline & \multirow[b]{2}{*}{ Enzyme } & \multirow[b]{2}{*}{$1.4 \times 10^{-3} \mathrm{M}$} & \multicolumn{2}{|c|}{$2.8 \times 10^{-3} \mathrm{M}$} \\
\hline & & & Exp. I & Exp. II \\
\hline $\begin{array}{r}\text { B. subtilis, } \\
\text { strain } 749\end{array}$ & $\begin{array}{l}\text { Basal } \\
\text { Induced }\end{array}$ & $\begin{array}{l}0.55 \\
0.61\end{array}$ & $\begin{array}{l}0 \cdot 54 \\
0 \cdot 61\end{array}$ & - \\
\hline $\begin{array}{l}\text { B. cereus, } \\
\text { strain } 569\end{array}$ & $\begin{array}{l}\text { Basal } \\
\text { Induced }\end{array}$ & $\begin{array}{l}0.58 \\
0 \cdot 60\end{array}$ & $\begin{array}{l}0 \cdot 64 \\
0 \cdot 64\end{array}$ & $\begin{array}{l}0 \cdot 65 \\
0 \cdot 69\end{array}$ \\
\hline
\end{tabular}

Test for presence of constitutive mutants in inducible cultures

The question posed in the introduction changes its nature somewhat if the amount of basal activity is only a reflexion of a greater or smaller proportion of genetically distinct constitutive mutant cells present in the inducible population under study. It would then be a matter of whether the penicillinases of two genetically distinct but very closely allied strains were of different molecular species and thus possibly produced by different mechanisms: and this might be considered less surprising than the possibility of two separate mechanisms controlling the formation of penicillinase in the same cell. Although such an explanation for basal activity has been proved reasonable for the $\beta$-galactosidase of Escherichia coli, ML strain, where the basal/inducible activity ratio is only $0.10 \%$ (Cohen-Bazire \& Jolit, 1953), it is rather less likely for the penicillinase of Bacillus cereus, strain 569, where the minimum ratio found is $0.5 \%$ and much more improbable for nitratase of $E$. coli, strain 1433 (ratio varying from $3 \%$ in washed suspensions without $\mathrm{N}$ source to $30 \%$ in high concentrations of casein hydrolysate-Wainwright, 1950), or for penicillinase of $B$. subtilis, strain 749 , with a ratio of 5 to $10 \%$. Even allowing for the possibility that constitutive mutant strains might produce, say, 10 times more enzyme than maximally induced adaptive strains, it would still mean an incidence of 1 constitutive mutant in a total of 2000 cells for cultures of $B$. cereus, strain 569, and 1 in 100 for B. subtilis, strain 749. Such a high proportion of mutants, if present, should be detectable without much difficulty. It might be considered that the best method for demonstrating the existence of constitutive mutants would be one analogous to that used by CohenBazire \& Jolit (1953) - viz. an attempted selection by alternate subcultures in media respectively with and without inhibiting concentrations of penicillin. However, an attempt to do this with $B$. cereus, strain 569 , by 50 passages in broth, containing $100 \mathrm{units} / \mathrm{ml}$. of penicillin on every alternate subculture, gave no significant increase in basal enzyme. The original intention was to give any cells producing penicillinase in large quantities without penicillin a slight selective advantage over the inducible cells when the culture was transferred to penicillin. It can, however, be argued that the production of penicillinase, 
particularly if exocellular, is a collective bacterial weapon against penicillin and might confer little or no selective growth advantage to the cells that form it, since its protective effect would be largely, if not entirely, shared by all cells in the culture. The following test was therefore devised in order to look for possible constitutive mutants.

Sandwich layer plates of CCY medium containing 1 vol. in 25 of a $0.5 \%$ aqueous solution of acid fuchsin, decolorized with $\mathrm{NaOH}$ (Andrade's indicator), were poured as follows: lower layer, $15 \mathrm{ml}$. containing $1.5 \%$ agar; middle layer, $7 \mathrm{ml}$. containing $3 \%$ agar $+1 \mathrm{ml}$. bacterial spores under test; upper layer, $7 \mathrm{ml}$. containing $3 \%$ agar. Plates were incubated overnight at $30^{\circ}$ and the following morning 300,000 units of penicillin in $2 \mathrm{ml}$. of water were added to the surface of each plate. Positive colonies producing large quantities of penicillinase constitutively, turn a bright red after about $15 \mathrm{~min}$. at room temperature. Negative colonies (i.e. non-penicillinase-producers or producers of penicillinase in large quantities only after induction by penicillin) remain colourless for several hours. 'Inducible' colonies can easily be distinguished from non-producers by incubating with a small quantity (100 units/plate) of penicillin at $35^{\circ}$ for $4 \mathrm{hr}$., after which the further addition of the full 300,000 units results in their going red within 15 min., like 'constitutives'. The efficacy of this test was checked with a constitutive-penicillinase mutant isolated by Dr P. H. A. Sneath from a strain of Bacillus cereus closely related to B. cereus, strain 569 . This mutant $(B$. cereus $5 / B$ ) forms about twice as much penicillinase constitutively as does $B$. cereus, strain 569 , under conditions for maximal adaptation. Artificial mixtures showed that it was easy to detect single colonies of $B$. cereus $5 / B$, by the above technique, against a background of up to 1000 colonies per plate of either B. cereus, strain 569 , or B. subtilis, strain 749 .

By this means, therefore, it was possible to examine 25,000 colonies of Bacillus subtilis, strain 749, and 16,000 colonies of $B$. cereus, strain 569; but not a single 'positive' colony of a constitutive penicillinase-producer was found.

\section{DISCUSSION}

It appears a priori rather unlikely that a homogeneous population of cells would produce the same highly complex protein, having a specific and presumably very restricted metabolic function, by two completely divergent pathways. The probability that the mechanism for its production is basically the same under two different conditions thus depends to a large extent on the demonstration that its properties, whatever the conditions of its formation, are constant.

The impossibility of obtaining large amounts of purified basal enzyme has meant that no comparison of properties such as amino-acid composition, electrophoretic mobility, molecular weight, turnover number or solubility in salts, etc., has been feasible; and it can always be argued that two apparently similar substances do in fact differ by some property which it has been impossible to study. Nevertheless, most catalytically similar enzyme preparations from even closely related types of cells show at least some immunological 
differences (see Sevag, 1945; Marrack, 1950); and, in the present work, it was not difficult to demonstrate fairly marked differences in $\mathrm{pH} /$ activity curves, Michaelis constants and immunological reactions between the penicillinases of two distinct species of the same genus. Even in the case of triose phosphate dehydrogenase studied by Velick \& Udenfriend (1953) where it was shown that, although the purified enzyme obtained from rabbit muscle had the same molecular weight and amino-acid composition as that extracted from yeast, the two were quite distinct immunologically and had different affinity constants for combination with diphosphopyridine nucleotide.

Thus, where the mechanism of formation of similar enzymes differs from one case to another, there seems to be a reasonable chance, even within the limited range of tests used here, of detecting differences in the properties of the product.

In this work no significant differences have been found between the basal and induced penicillinase fractions produced by either Bacillus subtilis, strain 749 , or $B$. cereus, strain 569. This supports the hypothesis that the mechanisms for the synthesis of basal and induced enzyme are fundamentally similar. In its simplest form such a hypothesis implies that the only difference lies in the extent to which the cells can themselves synthesize the necessary specific factor which evokes enzyme production; and that after the initial stages of inducer assimilation and metabolism the paths of synthesis are identical.

A special case of this hypothesis, put forward by Cohn \& Monod (1953) and by Pollock (1953), is that basal (constitutive) enzyme production is under the catalytic control of an endogenously produced 'organizer' whose synthesis in certain cases may be specifically augmented by addition of the exogenous inducer. It predicts that no consistent difference will be found between basal and induced enzyme in the same organism. In the case of penicillinase production by Bacillus cereus and by $B$. subtilis this prediction has so far been found to be true. The more evidence accrues, from the study of other systems and organisms, to confirm the similarity between basal and induced enzyme, the more important does it become to continue the search for a common pathway in their mode of production.

\section{REFERENCES}

Bernheim, F. (1950). The sarcosine oxidase in adapted and unadapted cultures of a strain of Pseudomonas aeruginosa. J. Bact. 60, 767.

Cohen-Bazire, G. \& Jolit, M. (1953). Isolement par sélection des mutants d'Escherichia coli synthétisant spontanément l'amylomaltase et la $\beta$-galactosidase. Ann. Inst. Pasteur, 84, 937.

Conn, M. \& Monod, J. (1953). Specific inhibition and induction of enzyme biosynthesis. Symp. Soc. gen. Microbiol. 3, 133.

Cohn, M. \& Torriani, A-M. (1953). The relationships in biosynthesis of the $\beta$-galactosidase and Pz-proteins in Escherichia coli. Biochim. Biophys. Acta, 10, 280.

Gradstone, G. P. \& Fildes, P. (1940). A simple culture medium for general use without meat extract or peptone. Brit. J. exp. Path. 21, 161.

Hartley, P. (1922). The value of Douglas's medium for the production of diphtheria toxin. J. Path. Bact. 25, 479. 
Henry, R. J. \& Housewright, R. D. (1947). Studies in penicillinase. II. Manometric method of assaying penicillinase and penicillin, kinetics of the penicillinpenicillinase reaction and the effect of inhibitors on penicillinase. J. biol. Chem. $167,559$.

Leeson, F. (1950). Penicillinase (its production and uses). Lab. J. 8, 316.

Lindegren, C. C. \& Palleroni, N. J. (1952). Absence of the preadaptive utilization of galactose by yeasts. Nature, Lond. 169, 879.

Manson, E. E. D. \& Pollock, M. R. (1953). The thermostability of penicillinase. J. gen. Microbiol. 8, 163.

Marrack, J. R. (1950). 'Enzymes and Immunology', ch. 8 of The Enzymes, vol. I, part I. Ed. by J. B. Sumner and K. Myrbäck. New York: Academic Press Inc.

Monod, J. \& CoHN, M. (1952). La biosynthèse induite des enzymes (adaptation enzymatique). Advanc. Enzymol. 13, 67.

Penau, J., Phillippe, J. \& Benoist, D. (1951). Méthode de titrage rapide de la pénicillinase. Ann. pharm. franc. 9, 419.

Pollock, M. R. (1952). Penicillinase adaptation in Bacillus cereus: An analysis of three phases in the response of logarithmically growing cultures to induction of penicillinase formation by penicillin. Brit. J. exp. Path. 33, 587.

PoLLock, M. R. (1953).. Stages in enzyme formation. Symp. Soc. gen. Microbiol. 3, 150.

Pollock, M. R. \& Perret, C. J. (1953). Penicillinase adaptation and fixation of penicillin sulphur by Bacillus cereus spores. J. gen. Microbiol. 8, 186.

Pollock, M. R. \& Torriani, A-M. (1953). Purification et caractéristiques physicochimiques de la pénicillinase de Bacillus cereus. C.R. Acad. Sci., Paris., 237, 276.

Reiner, J. M. \& Spiegelman, S. (1947). The pre-adaptive oxidation of galactose by yeast. J. gen Physiol. 31, 51.

SevaG, M. G. (1945). Immunocatalysis. Baltimore: C. C. Thomas.

Velick, S. F. \& Udenfriend, S. (1953). The composition and amino acid endgroups of glyceraldehyde-3-phosphate dehydrogenases. J. biol. Chem. 203, 575 .

WAINWRIGHT, S. D. (1950). Formation of a bacterial adaptive enzyme system in the absence of substrate: production of nitratase by Bact. coli without nitrate. Brit. J. exp. Path. 31, 495. 